\title{
Association of novel single nucleotide polymorphisms of the $C X C R 1$ gene with the milk performance traits of Chinese native cattle
}

\author{
L. Zhou ${ }^{1,2}$, H.M. Wang ${ }^{2}$, Z.H. Ju' ${ }^{2}$, Y. Zhang', J.M. Huang ${ }^{2}$, C. Qi' \\ M.H. Hou ${ }^{2}$, L.G. An ${ }^{1}$, J.F. Zhong ${ }^{2}$ and C.F. Wang ${ }^{2}$ \\ ${ }^{1}$ College of Life Science, Shandong Normal University, Jinan, China \\ ${ }^{2}$ Dairy Cattle Research Center, Shandong Academy of Agricultural Science, \\ Jinan, China \\ Corresponding authors: C.F. Wang / L.G. An \\ E-mail: wangcf1967@163.com / anlg@sdnu.edu.cn
}

Genet. Mol. Res. 12 (3): 2725-2739 (2013)

Received September 27, 2012

Accepted March 25, 2013

Published July 30, 2013

DOI http://dx.doi.org/10.4238/2013.July.30.10

\begin{abstract}
Mastitis is an economically devastating disease affecting the dairy industry. Dairy cows with mastitis give reduced milk yield and produce milk that is unfit for consumption. The chemokine receptor CXCR1 is an excellent prospective genetic marker for mastitis resistance in cattle because it regulates neutrophil migration, killing, and survival during infection. We detected 4 single nucleotide polymorphisms (SNPs) of the CXCR1 gene in Chinese native cattle and analyzed their associations with milk traits. Screening for genetic variations in CXCRI among 648 Chinese Holstein, Luxi Yellow, and Bohai Black cattle by created restriction site polymerase chain reaction (PCR), nested PCR, and DNA sequencing revealed 4 new SNPs with allelic frequencies ranging from 0.676 to $0.821,0.706$ to $0.803,0.647$ to 0.824 , and 0.558 to 0.581 . All four $C X C R 1$ gene SNPs were located in exon II. Two SNPs, c.337A $>\mathrm{G}$ and c. 365C $>\mathrm{T}$, were nonsynonymous mutations [ATC (Ile) > GTC (Val) and GCC (Ala) > GTC (Val)], whereas two, c.291C $>$ T and c.333C $>$ T, were synonymous mutations [TTC (Gly) $>$ TTT (Gly) and GGC (Phe) > GGT (Phe)]. Statistical analyses revealed
\end{abstract}


the significant association of c. $337 \mathrm{~A}>\mathrm{G}$ and c. $365 \mathrm{C}>\mathrm{T}$ with the somatic cell score, which suggests the possible role of these SNPs in the host response against mastitis. Our data suggest that combined genotypes CCAC/CCGC, CCAC/CTAT, and CCAT/CTAT (lowest somatic cell scores); CTAC/CTAT (highest protein rate); CCAC/CTGC (highest fat rate); and CCAT/CTAT (highest 305-day milk yield) can be used as possible candidates for marker-assisted selection in dairy cattle breeding programs.

Key words: Chinese native cattle; CXCR1; SNPs; Milk traits; SCS

\section{INTRODUCTION}

Mastitis, an inflammation of the mammary gland caused predominantly by bacteria, induces minor to fatal illness in affected dairy cattle. Mastitis causes major economic losses because of the reduction in milk yield and the wastage of milk unfit for consumption, as well as the required massive antibiotic use, and it is a major cause of premature culling. Neutrophils are a critical component of the effective elimination of bacterial infections by the host because of their ability to migrate from the blood to the infected mammary gland tissues and to remove the invading bacteria through phagocytosis, secretion of granule contents, reactive oxygen species generation, and subsequent protease activation (Reeves et al., 2002). Genes associated with neutrophil function are potential genetic markers for disease resistance, because neutrophil migration and functionality are essential for the resolution of bacterial infections (Paape et al., 2000; Kehrli and Harp, 2001).

The chemokine receptor CXCR1 has been implicated as a prospective genetic marker for mastitis resistance in dairy cows. First, CXCR1 is expressed on the surface of neutrophils (Proudfoot, 2002) and is essential for neutrophil migration to the mammary glands and the resolution of bacterial infections (Del Rio et al., 2001). Additionally, the CXCR1 locus has been genetically mapped close to other known loci that encode disease-resistance genes (Grosse et al., 1999). Third, the CXCR1 mRNA concentration was increased 607.6-fold when Escherichia coli elicited acute mastitis in the udder, using Affymetrix transcriptome microarrays (Günther et al., 2009). Furthermore, recent research has demonstrated an association between the incidence of subclinical intramammary infections and polymorphisms in the CXCR1 gene in Holstein dairy cows (Youngerman et al., 2004a). The $C X C R 1$ annotation was recently corrected by Pighetti and Rambeaud (2006), who demonstrated that the published CXCR2 sequence under GenBank reference No. NM_174360.2 actually corresponds to CXCR1, by comparison of the sequences of genomic DNA and full-length reverse transcription polymerase chain reaction (PCR) products homologous to human CXCR1 and CXCR2. Finally, the activity of the CXCR1 receptor is strongly associated with the inflammatory response to Gram-negative bacterial infections (Rainard and Riollet, 2006; Oviedo-Boyso et al., 2007), and CXCR1 expression could be induced by bacterial membrane components such as lipopolysaccharides via interaction with the Toll-like receptor 4 complex.

The CXCR1 gene, located on autosome 2 at $90.3 \mathrm{cM}$ in Bos taurus, contains a 2219-bp intron, an 87-bp exon I, and a 1713-bp exon II with a 1081-bp open reading frame (Pighetti et al., 2012). The associations between several single nucleotide polymorphisms (SNPs) 
and milk somatic cell score (SCS) in cattle have been identified in the bovine CXCRI gene (Youngerman et al., 2004a; Leyva-Baca et al., 2008; Goertz et al., 2009; Pighetti et al., 2012), indicating a typical significant association between SCS and CXCR1 c. $777 \mathrm{G}>\mathrm{C}$ variations in US Holstein-Friesians (Youngerman et al., 2004b), or CXCR1 c.-1768T >A in Canadian Holsteins (Leyva-Baca et al., 2008). However, no significant association between CXCR1 c. $777 \mathrm{G}>\mathrm{C}$ or $C X C R 1$ c.-1768T $>$ A and SCS was found by Goertz et al. (2009).

Chinese Holstein cows come from the selection and cross-breeding of a native Chinese cow and a purebred Holstein bull (Qiu, 2002). The frequency of mastitis in Chinese Holstein cows is about 38 to 50\% (Tao et al., 2007). Luxi Yellow and Bohai Black cattle are two of the representative indigenous bovine (B. taurus) breeds in China, which have been bred as beef and draft dual-purpose cattle for thousands of years because of their low disease susceptibility and high endurance under unfavorable feeding conditions. Understanding the association between disease resistance and production traits is useful in improving breeding techniques. In this study, we identified the CXCRI gene polymorphisms in all three Chinese cattle breeds. We then evaluated the correlation of these polymorphisms with various milk traits, such as the SCS of the $C X C R 1$ gene and $C X C R 1$ gene expression in the different tissues of Chinese Holstein cattle, using the quantitative real-time PCR to find genetic markers for lower SCS and mastitis resistance in dairy cattle.

\section{MATERIAL AND METHODS}

\section{Animal}

Three Chinese bovine breeds, namely, Chinese Holstein $(\mathrm{N}=528)$, Luxi Yellow $(\mathrm{N}=$ 86), and Bohai Black $(\mathrm{N}=34)$, were used in this study. Luxi Yellow and Bohai Black cattle, with an average age of 14 months, were randomly selected from their original conservation areas. A total of 528 Chinese Holstein cows (4 to 7 years old; calf number, 1 to 4 ) were randomly selected from three dairy cattle farms with complete lactation Dairy Herd Improvement records in the Tianjin, Jinan, and Qingdao agricultural development areas, China. Four traits (viz., SCS, 305-day mature equivalent, fat rate, and protein rate) were used for the association analyses.

\section{DNA extraction and polymorphisms}

Blood samples were collected from the jugular veins of the cows and placed in tubes with acid-citrate-dextrose anticoagulant $(0.48 \%$ citric acid, $1.32 \%$ citrate sodium, $1.47 \%$ dextrose) at a ratio of 6:1 (blood:acid-citrate-dextrose anticoagulant) for genomic DNA extraction according to the method described by Wang et al. (2011). The DNA content was spectrophotometrically estimated and the genomic DNA was diluted to $50 \mathrm{ng} / \mu \mathrm{L}$.

The $C X C R 1$ gene was amplified using nested PCR because of the $84 \%$ similarity between bovine $C X C R 1$ and $C X C R 2$. The first PCR product was diluted 100 times for use as the DNA template for the second PCR amplification. Five primer pairs for the bovine CXCRI gene (GenBank accession No. NM_001105038.1; http://www.ncbi.nlm.nih.gov/nuccore/ NM_001105038.1) were designed using the Primer Premier 5.0 software (Premier Biosoft International, Palo Alto, CA, USA) and synthesized by Sangon Biological Engineering Technology (Shanghai, China) (Table 1). The PCR was performed in a final volume of $25 \mu \mathrm{L}$ con- 
taining $50 \mathrm{ng}$ template DNA, $0.5 \mu \mathrm{M}$ of each primer, $0.2 \mathrm{mM}$ dNTPs, $2.5 \mathrm{mM} \mathrm{MgCl}$, and 0.5 U Taq DNA polymerase (TaKaRa, Dalian, China). The PCR conditions were as follows: initial denaturation at $94^{\circ} \mathrm{C}$ for $5 \mathrm{~min}$; followed by 35 cycles of denaturation at $94^{\circ} \mathrm{C}$ for $30 \mathrm{~s}$, annealing temperature for $30 \mathrm{~s}$ (as in Table 1), and elongation at $72^{\circ} \mathrm{C}$ for $30 \mathrm{~s}$; and a final extension at $72{ }^{\circ} \mathrm{C}$ for $7 \mathrm{~min}$. The PCR products were evaluated using $1.0 \%$ agarose gel electrophoresis and visualized with ethidium bromide staining.

\begin{tabular}{|c|c|c|c|c|c|}
\hline Gene & Primer sequences $\left(5^{\prime} \rightarrow 3^{\prime}\right)$ & $\begin{array}{l}\text { Product size } \\
\text { (bp) }\end{array}$ & $\begin{array}{l}\text { Annealing temperature } \\
\left({ }^{\circ} \mathrm{C}\right)\end{array}$ & Restriction enzyme & RES (bp) \\
\hline CXCR1 & $\begin{array}{l}\text { F: AGGGGTTTGAGGATGAGTTTG } \\
\text { R: TAGGTCGGAGTATGGTGGTTG }\end{array}$ & 536 & 62 & & \\
\hline c. $291 \mathrm{C}>\mathrm{T}$ & $\begin{array}{l}\text { F: AGGGGTTTGAGGATGAGTTTG } \\
\text { R: CCAGATAGGCAGGGTCATGTC }\end{array}$ & 266 & 59 & $\operatorname{Taq} \mathrm{I}$ & $\begin{array}{l}\text { CC: } 244 \\
\text { CT: } 244,22,266 \\
\text { TT: } 266\end{array}$ \\
\hline c. $333 \mathrm{C}>\mathrm{T}$ & $\begin{array}{l}\text { F: GCCTCCAAGGCAACGCG } \\
\text { R: AGGGCCAGGATCACGGACA }\end{array}$ & 218 & 53 & $M l u \mathrm{I}$ & $\begin{array}{l}\text { CC: } 218 \\
\text { CT: } 218,13,205 \\
\text { TT: } 205\end{array}$ \\
\hline c. $337 \mathrm{~A}>\mathrm{G}$ & $\begin{array}{l}\text { F: TCTATGCCCTGGTCTTCTTG } \\
\text { R: CAGGGGTGTGCCGAGGA }\end{array}$ & 193 & 58 & BamHI & $\begin{array}{l}\text { AA: } 193 \\
\text { AG: } 193,18,175 \\
\text { GG: } 175\end{array}$ \\
\hline c. $365 \mathrm{C}>\mathrm{T}$ & $\begin{array}{l}\text { F: CACCCCTGTGCAAGGAGG } \\
\text { R: TAGGTCGGAGTATGGTGGTTG }\end{array}$ & 236 & 58 & StuI & $\begin{array}{l}\text { CC: } 193,25,18 \\
\text { CT: } 193,18,211,25 \\
\text { TT: } 211,25\end{array}$ \\
\hline
\end{tabular}

RES = size of fragments at the indicated allele after digestion of the PCR product using the respective restriction enzyme. Underlined nucleotides = nucleotide mismatches that enabled the creation of a restriction enzyme site for discriminating sequence variations.

The PCR products with different electrophoretic patterns were directly sequenced in both directions using an ABI PRISM 3730 DNA analyzer (Applied Biosystems, Foster City, CA, USA) following the standard protocol. The DNAMAN software package (Version 6.0; Lynnon Biosoft, Quebec, Canada) was used to analyze the sequencing results and to determine the mutation position.

Created restriction site (CRS)-PCR is a simple and efficient method for identifying SNP genotypes. One or more mismatched primer bases are used to create a restriction site by combining the SNP site after PCR. The CRS-PCR products were genotyped using PCR restriction with fragment length polymorphism (PCR-RFLP). Four novel SNPs (c.291C > T, c. $333 \mathrm{C}>\mathrm{T}$, c.337A $>\mathrm{G}$, and c. $365 \mathrm{C}>\mathrm{T}$ ) were found in the $C X C R 1$ exon II region and genotyped via CRS-PCR using a primer containing a nucleotide mismatch, which enabled the use of the restriction enzymes TaqI, MluI, BamHI, and StuI for discriminating sequence variations, because none of the 4 SNP information for bovine CXCR1 was accessible (Wang et al., 2011). The PCR products were digested with the corresponding restriction endonucleases at $37^{\circ} \mathrm{C}$ for $8 \mathrm{~h}$, according to manufacturer recommendations. The restriction enzymes and fragment lengths of the products are listed in Table 1 . The digested products were detected by $12 \%$ polyacrylamide gel electrophoresis (29:1 acrylamide-bisacrylamide; $80 \times 73 \times 0.75 \mathrm{~mm})$ in 9X Tris-borate-EDTA buffer at a constant voltage of $110 \mathrm{~V}$ for $4 \mathrm{~h}$ at room temperature. The gel was stained with $0.1 \%$ silver nitrate. The genotype was estimated based on the different electrophoretic patterns. 


\section{Fluorescence quantitative real-time PCR}

Normal mammary tissues from 30 culled Chinese Holstein cattle were obtained immediately after slaughter and flash frozen in liquid nitrogen until RNA isolation. Total RNA was isolated from the mammary tissues using Trizol reagent (Bioteke, Beijing, China) according to manufacturer instructions. RNA was then treated with RNase-free DNase (Promega) to remove all genomic DNA contaminants. The RNA quality was assessed by measuring the relative absorbance at 260 and $280 \mathrm{~nm}$. Electrophoresis on agarose gels under denaturing conditions was performed to confirm the integrity of the ribosomal RNA bands. cDNA was synthesized using a Transcriptor First-Strand cDNA Synthesis kit (TaKaRa). Realtime PCR was performed in a $20-\mu \mathrm{L}$ mixture containing $50 \mathrm{ng} \mathrm{cDNA}, 0.4 \mu \mathrm{M}$ of each sense and antisense primers, $6.8 \mu \mathrm{L} \mathrm{ddH}_{2} \mathrm{O}, 10.0 \mu \mathrm{L} 2 \mathrm{X} \mathrm{SYBR}^{\circledR}$ Premix Ex Taq ${ }^{\mathrm{TM}}$, and $0.4 \mu \mathrm{L} 50 \mathrm{X}$ ROX reference dye (TaKaRa). The $\beta$-actin gene was used as an endogenous control to normalize the differences in the amount of total cDNA added to each reaction. The reaction mixture was denatured for $30 \mathrm{~s}$ at $95^{\circ} \mathrm{C}$, followed by 40 cycles of $95^{\circ} \mathrm{C}$ for $5 \mathrm{~s}$ and $60^{\circ} \mathrm{C}$ for $31 \mathrm{~s}$. The primers used were as follows: sense: 5'-ACCACCATACTCCGACCTA-3' and antisense: 5'-ACGAGCACGACAGCAAA-3' for CXCR1 (GenBank accession No. NM_001105038) and sense: 5'-TTAGCTGCGTTACACCCTT-3' and antisense: 5'-TGTCACCTTC $\bar{C}$ ACCGTTCC-3' for the $\beta$-actin gene (NM_173979.3). The PCR was monitored on an ABI PRISM 7000HT Fast Real-Time PCR system (Applied Biosystems). Relative quantification of CXCR1 gene expression was calculated using a standard curve-based method for relative real-time PCR.

\section{Statistical analyses}

The genotypic and allelic frequencies of each SNP, chi-square test for Hardy-Weinberg equilibrium, polymorphism information content (PIC), expected heterozygosity $\left(H_{\mathrm{E}}\right)$, and effective number of alleles $\left(N_{\mathrm{E}}\right)$ were analyzed using the TFPGA software. Linkage disequilibrium and haplotypic analyses were performed using the SHEsis software (Shi and He, 2005).

Differences in CXCRI gene expression between healthy and infected mammary tissues were tested using a paired $t$-test with SPSS version 11 (SPSS Inc., USA). Correlation analyses of single and combined $C X C R 1$ gene SNPs with milk traits were analyzed using the least-squares method in the general linear model procedure of SAS version 8.1 (SAS Institute, Inc., 2000). The linear model is $Y_{\mathrm{ijkml}}=\mu+G_{\mathrm{i}}+Y S_{\mathrm{j}}+H_{\mathrm{k}}+P_{1}+F S_{\mathrm{m}}+e_{\mathrm{ijkml}}$, where $Y_{\mathrm{ijkml}}$ is the observed value of each milk trait, $\mu$ is the overall mean, $G_{\mathrm{i}}$ is the fixed effect of genotype or combined genotype, $Y S_{\mathrm{j}}$ is the fixed effect of season, $H_{\mathrm{k}}$ is the fixed effect of farm, $P_{1}$ is the fixed effect of parity, $F S_{\mathrm{m}}$ is the random effect of sire, and $e_{\mathrm{ijkml}}$ is the random error. Differences with $\mathrm{P}$ values of less than 0.05 were considered to be significant.

\section{RESULTS}

\section{SNPs of the CXCR1 gene in three cattle breeds}

The present study detected 4 new SNPs (c.291C $>$ T, c. $333 \mathrm{C}>\mathrm{T}$, c.337A $>\mathrm{G}$, and c. $365 \mathrm{C}>\mathrm{T}$ ) within exon II by comparing the sequences with the annotated bovine CXCR1 sequence (GenBank accession No. NM_001105038.1; Figure 1). The SNPs c.291C $>$ T and 
c. 333C $>$ T were identified as synonymous mutations TTC (Gly) $>$ TTT (Gly) at the 97th amino acid within the putative second intercellular loop of the receptor region for $\mathrm{G}$ protein coupling activation, and GGC (Phe) $>$ GGT (Phe) at the 111th position. The SNPs c.337A $>$ G and c. $365 \mathrm{C}>\mathrm{T}$ were identified as nonsynonymous mutations ATC (Ile) $>$ GTC (Val) at the 113th amino acid and GCC (Ala) > GTC (Val) at the 122nd amino acid within the putative 3rd intercellular loop of the receptor region for $\mathrm{G}$ protein coupling activation of CXCR1 (360 amino acids). The four SNPs were submitted to the National Center for Biotechnology Information database (submission Nos. c.291C $>$ T, ss289379466; c.333C $>$ T, ss289379467; c.337A $>$ G, ss289379469; and c.365C > T, ss289379469).

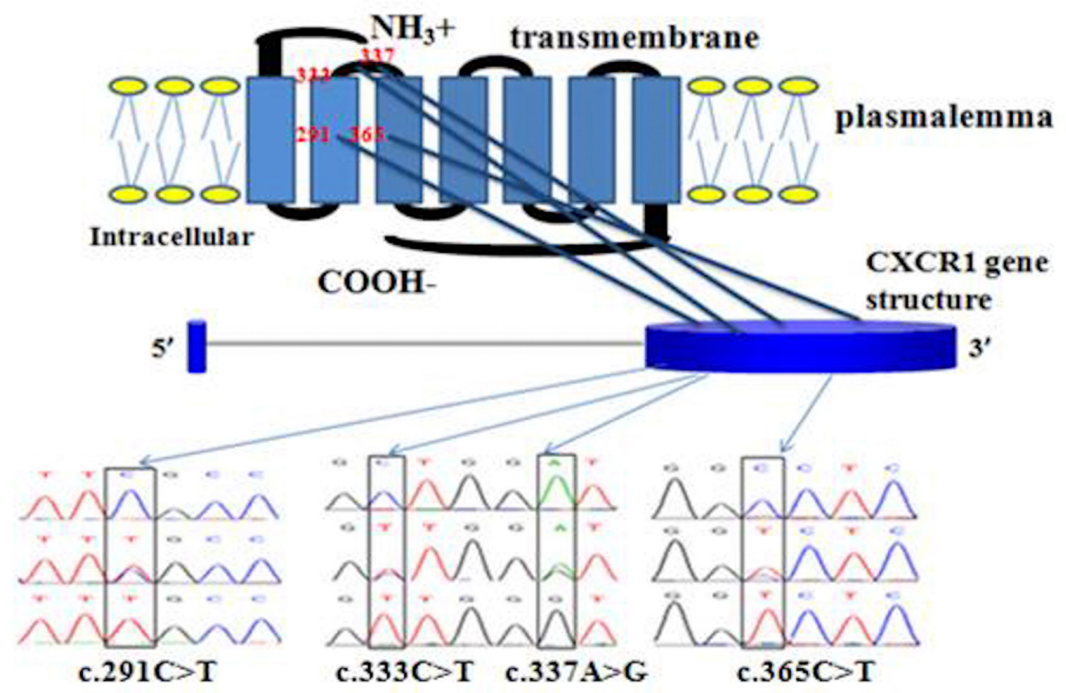

Figure 1. CXCRI structure, location of single nucleotide polymorphisms, and sequencing results of the three genotypes at sites c.291C $>$ T ss289379466, c.333C $>$ T ss289379467, c.337A $>$ G ss 289379469 , and c. $365 C>T$ ss289379469. CXCR1 structure shows exon 2 encoding the CXCR1 protein that contains seven putative transmembrane domains, whereas exon 1 near the 5 ' region represents non-coding protein region.

\section{PCR-RFLP and allele frequencies}

Digestion of the PCR product with TaqI (containing the CXCR1 c.291C>T locus) generated a 244-bp fragment for genotype CC; 244-, 22-, and 266-bp fragments for genotype CT; and a 266-bp fragment for genotype TT. Digestion with MluI (containing the CXCR1 c.333C $>$ T locus) generated a 218-bp fragment for genotype CC; 218-, 13-, and 205-bp fragments for genotype CT; and a 205-bp fragment for genotype TT, because of a nucleotide substitution. Digestion of the PCR fragment with BamHI (containing the CXCR1 c.337A>G locus) produced one band (193 or $175 \mathrm{bp}$ ) and three bands (193, 18, and $175 \mathrm{bp}$ ) for AA, GG, and AG (Figure 2). Digestion of the PCR product with $S t u$ I (containing the $C X C R 1$ c.365C $>$ T locus) generated 193-, 25- and 18-bp fragments for genotype CC; 193-, 18-, 25-, and 211-bp fragments for genotype CT; and 211- and 25-bp fragments for genotype TT. The 18-, 25-, 13-, and 22-bp fragments were not detectable on the gel because of their small sizes (Figure 2). 


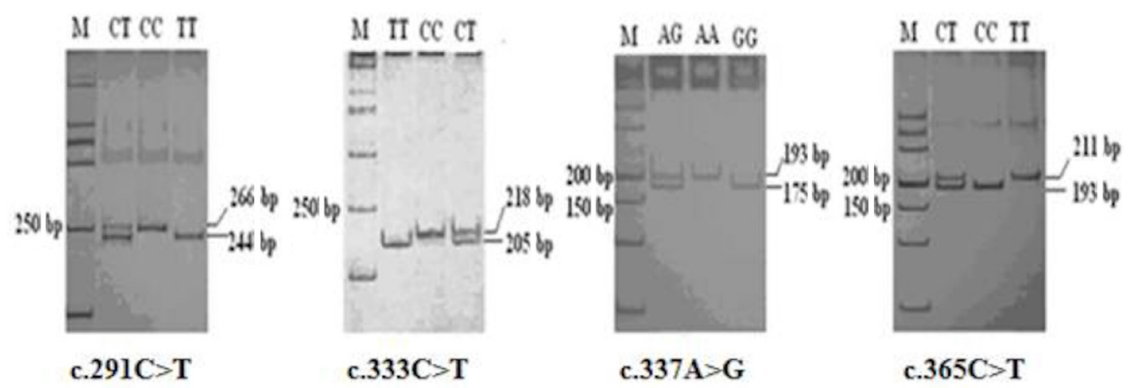

Figure 2. PCR-RFLP patterns of four bovine CXCR1 gene loci. Locus c.291C >T ss289379466 patterns: genotypes CT, CC, and TT; locus c.333C > T ss289379467 patterns: genotypes TT, TC, and CC; locus c.337A>G ss289379469 patterns: genotypes AA, AG, and GG; locus c.365C>T ss289379469 patterns: genotypes TT, TC, and CC. Digested products below $50 \mathrm{bp}$ are not shown. Lane $M=$ marker.

The allele and genotype frequencies of the 4 SNPs in the bovine $C X C R 1$ gene are shown in Table 2. The alleles C, C, A, and C were the predominant alleles at positions c.291C>T, c. $333 \mathrm{C}>\mathrm{T}, \mathrm{c} .337 \mathrm{~A}>\mathrm{G}$, and c.365 $\mathrm{C}>\mathrm{T}$, respectively, in the three breeds. The frequencies of allele $\mathrm{C}$ in the Chinese Holstein, Luxi Yellow, and Bohai Black breeds were 0.821, 0.669, and 0.676, respectively, at c.291C $>\mathrm{T}$; and $0.803,0.744$, and 0.706 , respectively, at c. $333 \mathrm{C}>\mathrm{T}$. The frequencies of allele A in the Chinese Holstein, Luxi Yellow, and Bohai Black breeds were 0.699, 0.647, and 0.824 , respectively, at c.337A $>\mathrm{G}$; and $0.564,0.581$, and 0.558 , respectively, at c. $365 \mathrm{C}>\mathrm{T}$.

\begin{tabular}{|c|c|c|c|c|c|c|c|c|c|}
\hline \multirow{2}{*}{$\begin{array}{l}\text { Breed } \\
\text { c.291C }>T\end{array}$} & \multicolumn{3}{|c|}{ Observed genotype } & \multicolumn{2}{|c|}{ Allelic frequency } & \multirow[t]{2}{*}{ PIC } & \multirow[t]{2}{*}{$N_{\mathrm{E}}$} & \multirow[t]{2}{*}{$H_{\mathrm{E}}$} & \multirow[t]{2}{*}{$\chi^{2}$ test $(\mathrm{P})$} \\
\hline & $\mathrm{CC}$ & CT & TT & $\mathrm{C}$ & $\mathrm{T}$ & & & & \\
\hline $\mathrm{CH}$ & 0.667 & 0.309 & 0.025 & 0.821 & 0.179 & 0.251 & 1.416 & 0.293 & $1.343(0.246)$ \\
\hline 528 & 352 & 163 & 13 & & & & & & \\
\hline LY & 0.360 & 0.616 & 0.023 & 0.669 & 0.331 & 0.345 & 1.796 & 0.443 & $13.127(0.0003)$ \\
\hline 86 & 31 & 53 & 2 & & & & & & \\
\hline BB & 0.382 & 0.588 & 0.029 & 0.676 & 0.324 & 0.342 & 1.778 & 0.438 & $4.020(0.045)$ \\
\hline 34 & 13 & 20 & 1 & & & & & & \\
\hline c. $333 \mathrm{C}>\mathrm{T}$ & $\mathrm{CC}$ & $\mathrm{CT}$ & TT & $\mathrm{C}$ & $\mathrm{T}$ & & & & \\
\hline $\mathrm{CH}$ & 0.648 & 0.310 & 0.042 & 0.803 & 0.197 & 0.266 & 1.463 & 0.316 & $0.174(0.677)$ \\
\hline 528 & 342 & 164 & 22 & & & & & & \\
\hline LY & 0.488 & 0.511 & 0 & 0.744 & 0.256 & 0.308 & 1.615 & 0.381 & $10.162(0.001)$ \\
\hline 86 & 42 & 44 & & & & & & & \\
\hline BB & 0.411 & 0.588 & 0 & 0.706 & 0.294 & 0.329 & 1.710 & 0.415 & $5.903(0.015)$ \\
\hline 34 & 14 & 20 & & & & & & & \\
\hline c. $337 \mathrm{~A}>\mathrm{G}$ & AA & $\mathrm{AG}$ & $\mathrm{GG}$ & A & G & & & & \\
\hline $\mathrm{CH}$ & 0.479 & 0.439 & 0.081 & 0.699 & 0.301 & 0.332 & 1.727 & 0.421 & $1.019(0.313)$ \\
\hline 528 & 253 & 232 & 43 & & & & & & \\
\hline LY & 0.340 & 0.614 & 0.045 & 0.647 & 0.352 & 0.352 & 1.839 & 0.456 & $10.453(0.001)$ \\
\hline 86 & 30 & $\begin{array}{l}54 \\
54\end{array}$ & $\begin{array}{l}0.07 \\
4\end{array}$ & & & & & & \\
\hline BB & 0.647 & 0.353 & 0.00 & 0.824 & 0.176 & 0.248 & 1.410 & 0.291 & $1.561(0.211)$ \\
\hline 34 & 22 & 12 & & & & & & & \\
\hline c. $365 \mathrm{C}>\mathrm{T}$ & $\mathrm{CC}$ & $\mathrm{CT}$ & $\mathrm{TT}$ & $\mathrm{C}$ & $\mathrm{T}$ & & & & \\
\hline $\mathrm{CH}$ & 0.280 & 0.568 & 0.152 & 0.564 & 0.436 & 0.371 & 1.967 & 0.492 & $12.772(0.0003)$ \\
\hline 528 & 148 & 300 & 80 & & & & & & \\
\hline LY & 0.291 & 0.581 & 0.127 & 0.581 & 0.418 & 0.368 & 1.948 & 0.487 & $3.252(0.071)$ \\
\hline 86 & 25 & 50 & 11 & & & & & & \\
\hline $\mathrm{BB}$ & 0.353 & 0.412 & 0.235 & 0.558 & 0.441 & 0.372 & 1.972 & 0.493 & $0.925(0.441)$ \\
\hline 34 & 12 & 14 & 8 & & & & & & \\
\hline
\end{tabular}
$N_{\mathrm{E}}=$ effective number of alleles; PIC $=$ polymorphism information content. 
The genetic indices $\left(H_{\mathrm{E}}, N_{\mathrm{E}}\right.$, and PIC) of the three Chinese cattle populations were calculated according to the Nei method (Table 2). A chi-square test, as well as the $H_{\mathrm{E}}, N_{\mathrm{E}}$, and PIC analyses (Table 2), indicated that only the c.365C $>\mathrm{T}$ SNP failed to meet the Hardy-Weinberg equilibrium ( $\mathrm{P}$ $<0.05)$ in the Chinese Holstein cattle, whereas the g.365C $>$ T SNP met the equilibrium $(\mathrm{P}>0.05)$ in the Luxi Yellow cattle. For the Bohai Black cattle, the c.291C $>$ T and c.333C $>$ T SNPs met the equilibrium ( $\mathrm{P}>0.05)$, whereas c. $337 \mathrm{~A}>\mathrm{G}$ and c.365C $>\mathrm{T}$ failed to meet the equilibrium $(\mathrm{P}<0.05)$. The maximum PIC values for the c.291C $>$ T, c. 333C $>$ T, c. $337 \mathrm{~A}>\mathrm{G}$, and c. $365 \mathrm{C}>\mathrm{T}$ loci in the three breeds were $0.345,0.329,0.352$, and 0.372 , whereas the minimum PIC values were $0.251,0.266$, 0.248 , and 0.368 , respectively. According to the PIC classification (PIC value $<0.25$, low polymorphism; $0.25<$ PIC value $<0.5$, intermediate polymorphism; and PIC value $>0.5$, high polymorphism), the three Chinese cattle breeds possessed intermediate genetic diversity at the c.291C $>\mathrm{T}$, c.333C $>$ T, c.337A $>$ G, and c.365 C $>$ T loci, except for Bohai Black cattle at locus c.337A $>\mathrm{G}$.

\section{Relationships between the SNP and combined genotypes of the CXCR1 gene and bovine milk production traits}

The least-squares means and standard errors for the effects of the four loci of the CXCR1 gene on milk production traits (fat rate, protein rate, 305-day milk yields) and SCS of 528 Chinese Holstein cows are shown in Table 3 . The c.337A $>\mathrm{G}$ and c.365C $>$ T polymorphisms were both associated with differences in SCS $(\mathrm{P}<0.05)$. Animals with the AA genotype at positions 337 had significantly higher SCS values than those with genotypes GG and AG $(\mathrm{P}<0.05)$, and the cows with the TT genotype at position 365 had a significantly higher SCS than those with the CC genotype $(\mathrm{P}<0.05)$. However, no other significant associations were observed between the c.291C $>\mathrm{T}$ and c.333C $>$ T polymorphisms and the SCSs of the 528 Chinese Holstein population $(\mathrm{P}>0.05)$.

\begin{tabular}{|c|c|c|c|c|c|}
\hline Loci & Genotype/sample & Somatic cell score & Protein rate (\%) & Fat rate $(\%)$ & 305-day milk yield $(\mathrm{kg})$ \\
\hline \multirow[t]{6}{*}{ c. $291 \mathrm{C}>\mathrm{T}$} & $\mathrm{CC} / 352$ & $4.621 \pm 0.339$ & $3.035 \pm 0.010$ & $3.621 \pm 0.137$ & $6982.93 \pm 350.01$ \\
\hline & $\mathrm{CT} / 163$ & $4.523 \pm 0.337$ & $2.977 \pm 0.010$ & $3.570 \pm 0.136$ & $7032.90 \pm 348.86$ \\
\hline & $\mathrm{TT} / 13$ & $4.521 \pm 0.586$ & $3.038 \pm 0.171$ & $3.801 \pm 0.232$ & $6467.91 \pm 599.35$ \\
\hline & $\alpha \mathrm{s}_{1}$ & 0.036 & 0.005 & 0.010 & -171.4 \\
\hline & $\mathrm{d} 1$ & -0.018 & -0.845 & -0.010 & -119.3 \\
\hline & al & 0.042 & 0.035 & 0.010 & -130.59 \\
\hline \multirow{6}{*}{ c. $333 \mathrm{C}>\mathrm{T}$} & $\mathrm{CC} / 342$ & $4.580 \pm 0.320$ & $2.963 \pm 0.107^{\mathrm{B}}$ & $3.573 \pm 0.133$ & $7084.61 \pm 333.55$ \\
\hline & $\mathrm{CT} / 164$ & $4.593 \pm 0.359$ & $3.269 \pm 0.119^{\mathrm{A}}$ & $3.478 \pm 0.148$ & $6749.88 \pm 375.21$ \\
\hline & $\mathrm{TT} / 22$ & $5.220 \pm 0.587$ & $3.102 \pm 0.192$ & $3.671 \pm 0.238$ & $6756.59 \pm 597.69$ \\
\hline & $\alpha \mathrm{s}_{2}$ & 0.023 & 0.008 & 0.008 & -137.5 \\
\hline & $\mathrm{d} 2^{2}$ & 0.156 & 0.005 & 0.006 & -58.4 \\
\hline & $\mathrm{a} 2$ & -0.03 & 0.006 & 0.005 & -117.6 \\
\hline \multirow{6}{*}{ c. $337 \mathrm{~A}>\mathrm{G}$} & $\mathrm{AA} / 253$ & $4.359 \pm 0.430^{\mathrm{b}}$ & $3.026 \pm 0.114$ & $3.604 \pm 0.139$ & $7208.64 \pm 400.04^{a}$ \\
\hline & $\mathrm{AG} / 233$ & $4.433 \pm 0.322^{b}$ & $2.972 \pm 0.113$ & $3.556 \pm 0.137$ & $7025.21 \pm 386.17$ \\
\hline & $\mathrm{GG} / 43$ & $5.658 \pm 0.346^{\mathrm{a}}$ & $3.136 \pm 0.145$ & $3.322 \pm 0.177$ & $6467.28 \pm 504.04^{\mathrm{b}}$ \\
\hline & $\alpha s_{3}$ & -0.128 & 0.032 & -0.073 & -464.9 \\
\hline & $\mathrm{d}^{3} 3^{2}-2-3$ & 0.258 & -0.009 & 0.136 & $58.8^{*}$ \\
\hline & a3 & -0.217 & 0.035 & -0.119 & -485.0 \\
\hline \multirow{6}{*}{ c. $365 \mathrm{C}>\mathrm{T}$} & $\mathrm{CC} / 148$ & $4.254 \pm 0.266^{\mathrm{b}}$ & $3.073 \pm 0.117$ & $3.583 \pm 0.144$ & $7076.14 \pm 414.51$ \\
\hline & $\mathrm{CT} / 300$ & $4.709 \pm 0.380^{\mathrm{a}}$ & $3.003 \pm 0.113$ & $3.510 \pm 0.138$ & $6460.61 \pm 392.40^{\mathrm{b}}$ \\
\hline & $\mathrm{TT} / 80$ & $4.304 \pm 0.249$ & $2.925 \pm 0.122$ & $3.618 \pm 0.149$ & $7119.67 \pm 412.80^{\mathrm{a}}$ \\
\hline & $\mathrm{\alpha s}_{4}$ & 0.084 & -0.092 & -0.108 & 37.1 \\
\hline & $\mathrm{d} 44^{4}$ & -0.128 & -0.116 & $-0.084 *$ & 102.6 \\
\hline & a4 & 0.128 & -0.053 & -0.080 & 2.08 \\
\hline
\end{tabular}

Means with " $a$ " are significantly higher than the preceding values " $b$ " at $\mathrm{P}<0.05$; means with " $\mathrm{A}$ " are significantly higher than the preceding values "B" at $\mathrm{P}<0.01$. Means without any superscripted letters are not statistically different $(\mathrm{P}>0.05)$. 
The linkage disequilibrium between the four SNPs among the 528 Chinese Holstein cows was estimated $\left(D^{\prime}=0.105-0.506 ; \mathrm{r}^{2}=0.006-0.032\right)$, which indicated that the SNPs had weak linkage disequilibrium (Table 4). Four $C X C R 1$ SNPs (c.291C $>$ T, c.333C $>$ T, c.337A $>$ G, and c.365 $\mathrm{C}>\mathrm{T}$ ) were used for haplotype reconstruction. The haplotype frequencies for $\mathrm{H} 1$ : CCAC, H2: CCAT, H3: CCGC, H4: CCGT, H5: CTAC, H6: CTAT, H7: CTGC, H8: CTGT, H9: TCAC, H10: TCAT, H11: TCGC, H12: TCGT, H13: TTAC, H14: TTGC, H15: TTGT, and H16: TTAT were $0.288,0.228,0.117,0.019,0.058,0.058,0.001,0.059,0.034,0.089,0.025$, $0.016,0.007,0.005,0.002$, and 0.000 , respectively. The highest $\mathrm{H} 1$ frequency was $28.8 \%$, and the lowest $\mathrm{H} 16$ frequency was $0 \%$. A total of 20 combined haplotypes of the four SNPs were found, although 256 combinations were possible for the 528 Chinese Holstein cows. Six combined genotypes, H3H3 (1), H1H11 (2), H3H11 (1), H9H11 (1), H1H4 (1), and H2H4 (1), had less than four samples and were excluded in the association analysis (Table 5).

Results (Table 5) showed that milk production traits and SCSs significantly differed in various haplotype combinations. For the SCS, the number of subjects with the H6H6 haplotype combination was significantly higher than those with the H2H6, H1H6, and $\mathrm{H} 1 \mathrm{H} 3$ haplotype combinations $(\mathrm{P}<0.01)$. Subjects with haplotype combinations H1H6 and H1H13 showed significantly lower fat percentage than those with the H1H7 haplotype combination $(\mathrm{P}<0.01)$. Based on protein rate trait, the number of cows with the H5H6 haplotype combination was significantly higher than those with the $\mathrm{H} 1 \mathrm{H} 7$ and $\mathrm{H} 1 \mathrm{H} 9$ haplotype combinations (P $<0.01)$. The number of cows with the $\mathrm{H} 2 \mathrm{H} 6$ haplotype combination was significantly higher than with the H5H6, H6H6, H2H10, and H1H1 haplotype combinations $(\mathrm{P}<0.01)$ for the 305-day milk yield.

Table 4. Analysis of pairwise linkage disequilibrium in $C X C R$.

\begin{tabular}{lcccc}
\hline & c. $291 \mathrm{C}>\mathrm{T}$ & $\mathrm{c} .333 \mathrm{C}>\mathrm{T}$ & $\mathrm{c} .337 \mathrm{~A}>\mathrm{G}$ & $\mathrm{c} .365 \mathrm{C}>\mathrm{T}$ \\
\hline $\mathrm{c} .291 \mathrm{C}>\mathrm{T}$ & - & 0.506 & 0.105 & 0.322 \\
c. $333 \mathrm{C}>\mathrm{T}$ & 0.012 & - & 0.208 & 0.244 \\
c. $337 \mathrm{~A}>\mathrm{G}$ & 0.006 & 0.032 & - & 0.213 \\
c. $365 \mathrm{C}>\mathrm{T}$ & 0.032 & 0.016 & 0.015 & - \\
\hline
\end{tabular}

Linkage disequilibrium is above the diagonal for SNPs, and $\mathrm{r}^{2}$ is below the diagonal.

Table 5. GLM procedure least squares means of different traits in haplotype of CXCR1.

\begin{tabular}{|c|c|c|c|c|}
\hline Haplotype combinations/Samples & Somatic cell score & Protein rate $(\%)$ & Fat rate $(\%)$ & 305-day milk yield $(\mathrm{kg})$ \\
\hline H1H2(CCCCAACT)/135 & $4.816 \pm 0.443$ & $3.010 \pm 0.119$ & $3.581 \pm 0.166$ & $7198.57 \pm 536.86$ \\
\hline H1H1(CCCCAACC)/69 & $4.361 \pm 0.443$ & $3.210 \pm 0.118$ & $3.513 \pm 0.165$ & $6723.05 \pm 539.56^{\mathrm{B}}$ \\
\hline Н2H2(CCCCAATT) $/ 48$ & $4.248 \pm 0.551$ & $3.085 \pm 0.149$ & $3.312 \pm 0.208$ & $7063.27 \pm 654.83$ \\
\hline $\mathrm{H} 1 \mathrm{H} 3(\mathrm{CCCCAGCC}) / 51$ & $3.898 \pm 0.553^{\mathrm{B}}$ & $2.928 \pm 0.147$ & $3.419 \pm 0.205$ & $7076.01 \pm 646.86$ \\
\hline H1H5(CCCTAACC)/30 & $3.930 \pm 0.700$ & $3.136 \pm 0.176$ & $3.587 \pm 0.246$ & $7238.19 \pm 777.53$ \\
\hline H1H6(CCCTAACT)/36 & $3.053 \pm 0.603^{\mathrm{B}}$ & $3.162 \pm 0.162$ & $3.259 \pm 0.227^{\mathrm{B}}$ & $7258.22 \pm 715.35$ \\
\hline H2H6(CCCTAATT)/16 & $3.801 \pm 0.921^{\mathrm{B}}$ & $3.064 \pm 0.248$ & $3.597 \pm 0.348$ & $7368.4 \pm 1091.63^{\mathrm{A}}$ \\
\hline $\mathrm{H} 1 \mathrm{H} 7(\mathrm{CCCTAGCC}) / 9$ & $4.272 \pm 0.781$ & $2.873 \pm 0.211^{\mathrm{B}}$ & $3.677 \pm 0.295^{\mathrm{A}}$ & $7152.10 \pm 993.44$ \\
\hline H5H6(CCTTAACT $) / 18$ & $4.520 \pm 1.044$ & $3.376 \pm 0.282^{\mathrm{A}}$ & $3.412 \pm 0.394$ & $6245.48 \pm 1235.95^{\mathrm{B}}$ \\
\hline H6H6(CCTTAATT)/9 & $5.629 \pm 1.057^{\mathrm{A}}$ & $3.442 \pm 0.285$ & $3.514 \pm 0.399$ & $6310.83 \pm 1253.47^{\mathrm{B}}$ \\
\hline H1H9(CTCCAACC)/15 & $4.058 \pm 1.052$ & $2.846 \pm 0.284^{\mathrm{B}}$ & $3.645 \pm 0.397$ & $7040.70 \pm 1502.90$ \\
\hline $\mathrm{H} 1 \mathrm{H} 10(\mathrm{CTCCAACT}) / 45$ & $4.084 \pm 0.569$ & $3.226 \pm 0.153$ & $3.539 \pm 0.215$ & $6893.60 \pm 676.82$ \\
\hline $\mathrm{H} 2 \mathrm{H} 10(\mathrm{CTCCAATT}) / 27$ & $5.245 \pm 0.711$ & $3.245 \pm 0.192$ & $3.628 \pm 0.268$ & $6326.30 \pm 884.26^{\mathrm{B}}$ \\
\hline H1H13(CTCTAACC)/9 & $4.670 \pm 1.052$ & $3.169 \pm 0.284$ & $3.268 \pm 0.397^{\mathrm{B}}$ & $6787.11 \pm 1247.30$ \\
\hline
\end{tabular}

H1: CCAC, H2: CCAT, H3: CCGC, H4: CCGT, H5: CTAC, H6: CTAT, H7: CTGC, H9: TCAC, H10: TCAT, H13: TTAC. Means with "A" are very significantly higher than the preceding values "B" at $\mathrm{P}<0.01$. 


\section{Quantitative reverse-transcription PCR}

The differences in CXCR1 gene expression levels in the mammary tissues of the Chinese Holstein cattle with different genotypes at the c.337A $>\mathrm{G}$ and c.365C $>\mathrm{T}$ loci were also investigated (Figure 3). A total of 30 cows were divided into three groups based on genotypes AA $(\mathrm{N}=15), A G(\mathrm{~N}=12)$, and $\mathrm{GG}(\mathrm{N}=3)$ in c.337A $>\mathrm{G}$, and $\mathrm{CC}(\mathrm{N}=8), \mathrm{CT}(\mathrm{N}=17)$, and TT $(\mathrm{N}=5)$ in c.365C $>$ T. mRNA expression of the CXCR1 GG-c.337A $>$ G genotype was significantly higher than the AA-c.337A $>$ G genotype $(\mathrm{P}<0.05)$, and the expression of the CXCR1 CT-c.365C $>$ T was 1.5 -fold higher than the TT-c.365C $>$ T genotype, but the difference was not statistically significant ( $\mathrm{P}>0.05$; Figure 3 ). The mRNA abundance of the $C X C R 1$ GGc.337A $>$ G genotype was 2.4-fold higher than that of the AA-c.337A $>$ G genotype.
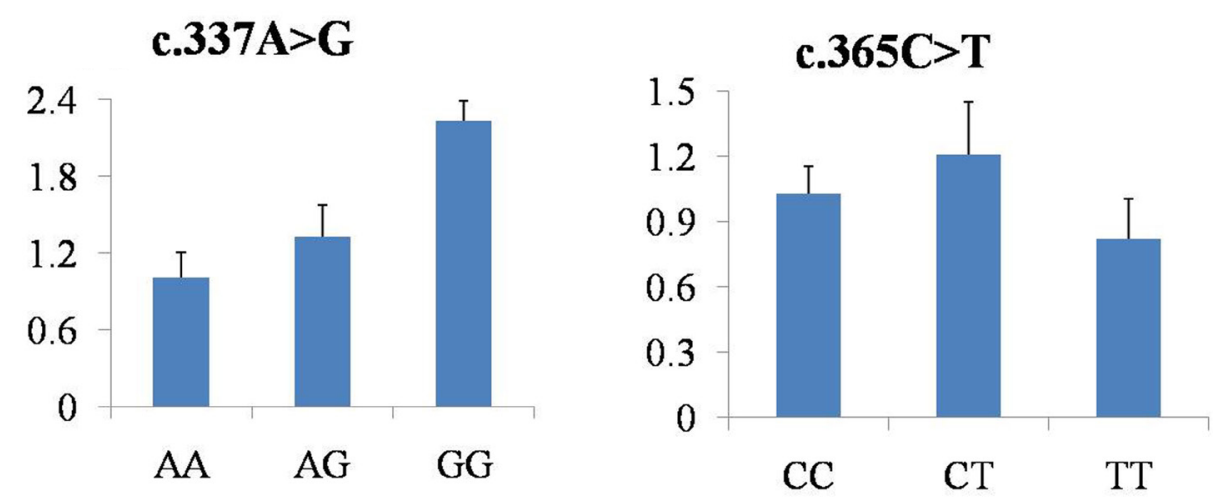

Figure 3. Quantitative reverse transcription-PCR detection of the $C X C R 1$ transcript in mammary tissues with different genotypes at c.337A $>\mathrm{G}$ and c.365C $>\mathrm{T}$. The 30 cows were divided into three groups based on genotypes $\mathrm{AA}(\mathrm{N}=15), \mathrm{AG}(\mathrm{N}=12)$, and $\mathrm{GG}(\mathrm{N}=3)$ at $\mathrm{c} .337 \mathrm{~A}>\mathrm{G}$ and $\mathrm{CC}(\mathrm{N}=8), \mathrm{CT}(\mathrm{N}=17)$, and $\mathrm{TT}(\mathrm{N}=5)$ at $\mathrm{c} .365 \mathrm{C}>\mathrm{T}$ locus. Differences in relative transcription level between different genotypes were highly significant $(\mathrm{P}<0.05)$.

\section{Three-dimensional protein structures and domains}

As shown in Figure 4, the 3-dimensional protein structures and domains of the mutation variants were predicted using SWISS-MODEL (http://swissmodel.expasy.org/) (Zdobnov and Apweiler, 2001; Arnold et al., 2006). Both CXCR1 structures consisted of three domains: i) IPR000276, rhodopsin-like GPCR superfamily, family (PF00001); ii) IPR000276, rhodopsin-like GPCR superfamily, family (PS50262); iii) noIPR, unintegrated (SSF81321). The CXCR1 structure did not change significantly based on the comparison between Figure $4 \mathrm{~A}$ and $\mathrm{B}$.

\section{DISCUSSION}

Four novel SNPs were identified within the 550-bp fragment of the putative exon II region of bovine CXCR1. Pighetti et al. (2012) demonstrated 36 point mutations in the coding region and surrounding sequences of $C X C R 1$ in 88 Holstein dairy cows, which is 


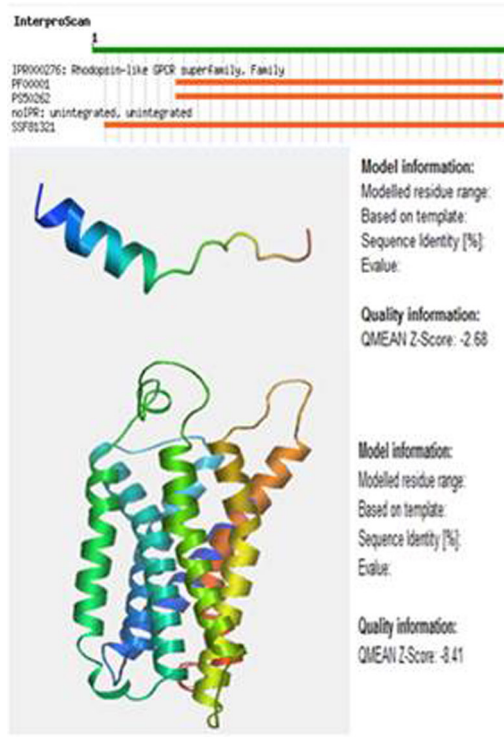

A

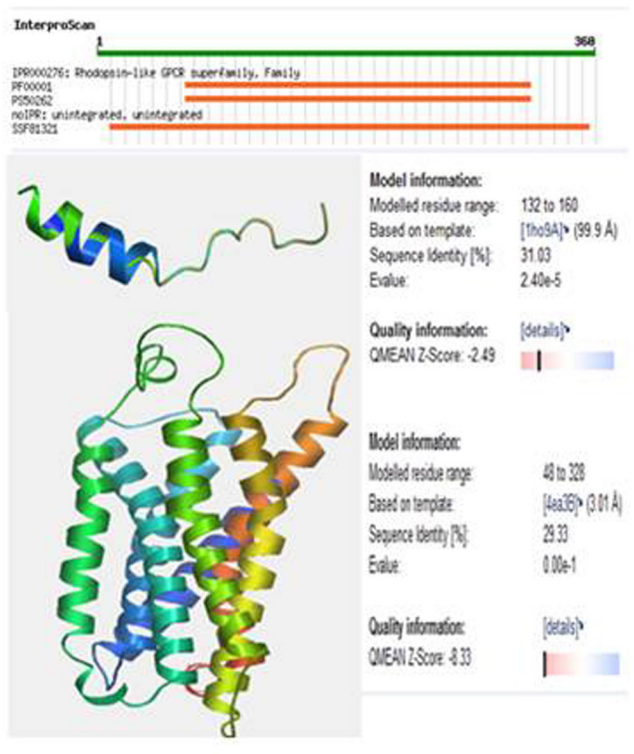

B

Figure 4. A. Putative protein structures and functional domains of the identified bovine CXCR1. B. Putative protein structures and functional domains of the mutation variant $(\mathrm{c} .337 \mathrm{~A}>\mathrm{G}, \mathrm{c} .365 \mathrm{C}>\mathrm{T})$ of the CXCR1.

consistent with the current findings. In particular, 11 nucleotide polymorphisms were located in the coding region: 4 introduced amino acid changes, 1 introduced a stop codon, and 6 were synonymous. According to the Human Genome Variation Society guidelines (http:// www.hgvs.org/mutnomen/recs.html), the number of polymorphisms is named with "A" of the ATG translation start site of the bovine CXCR1 sequence (GenBank accession No. NM_001105038.1) serving as position 1. The c.333C $>$ T SNP is equivalent to the previous c. 291 C $>$ T SNP reported by Pighetti et al. (2012). The result was not remarkable, because the annotations for $C X C R 1$ and its sequences were recently corrected by Pighetti and Rambeaud (2006) and by Lahouassa et al. (2008). Therefore, the previous association and functional studies for CXCR2 (GenBank accession No. NM 174360.2) performed by Youngerman et al. (2004a) and by Rambeaud and Pighetti (2005) correspond to CXCR1. The high degree of polymorphism of $C X C R 1$ was again verified. Numerous studies have revealed the importance of chemokines and chemokine receptors in inflammatory disease. The identification of potential genetic markers associated with the immune response could lead to the selection of mastitis-resistant cows and possibly improve their productive performance and survival. CXCR is one of the most important components of the innate immune system.

The correlation analysis suggested that the $C X C R 1$ gene is significantly correlated with cattle mastitis. Variations in several chemokine and chemokine receptor genes in inflammatory diseases are reportedly correlated with resistance. For example, the protein and mRNA expression of interleukin-8 have been associated with bovine mastitis (Lee et al., 2006). The effect of allelic substitution on the CCR2 rs41257559:C $>$ T SNP on SCS is significant (Leyva-Baca et al., 2008), and CCL2 polymorphisms have been associated with increased risk of rheumatoid 
arthritis (Gonzalez-Escribano et al., 2003), acute pancreatitis (Papachristou et al., 2005), and myocardial infarction in humans (Dewald et al., 2005; McDermott et al., 2005). Analysis of bovine CXCR1 SNPs may contribute to the discovery of mastitis resistance-related genetic traits, because bacteria are the most common cause of mastitis in cattle. The SCS has been used as a criterion for improving mastitis resistance (Shook and Schutz, 1994). Statistical analysis revealed that cows with c.337A $>$ G-AG and c.337A $>$ G-GG genotypes had significantly lower SCSs than the AA subjects, whereas the cows with c.365C $>$ T-CC had significantly lower SCSs than the TT subjects, which indicates that genotypes AG, GG, and TT might be associated with mastitis resistance. Allele $\mathrm{G}$ of SNPs c.337A $>\mathrm{G}$ and T of SNP c.365C $>$ T may predispose cows to clinical mastitis via increased neutrophil trafficking to the mammary gland, because clinical mastitis is moderately correlated with SCS, as reported by Rupp and Boichard (1999). Therefore, cattle with genotypes AG, AA, and CC can be selected for breeding. Our findings confirm that $C X C R 1$ c.337A $>\mathrm{G}$ and c.365C $>\mathrm{T}$ could be regarded as novel candidate genetic molecular markers for mastitis resistance/susceptibility in Chinese Holstein, similar to CXCR1 c. $+777 \mathrm{G}>\mathrm{C}$ in Jersey cattle (Youngerman et al., 2004a). The early neutrophil recruitment into the mammary gland is important for the resolution of mammary gland infection; furthermore, bovine CXCR 1 reportedly mediates cell migration in vitro (Lahouassa et al., 2008). Therefore, CXCR1 may have a potential role in the recruitment of bovine neutrophils into the mammary gland when an infection occurs. The nonsynonymous substitution at the $C X C R 1 \mathrm{c} .+777 \mathrm{G}>\mathrm{C}$ SNP resulted in the replacement of glutamine with histidine at amino acid 245 within the third intercellular loop of the receptor region for $\mathrm{G}$ protein coupling activation, which is related to the functional characteristics of neutrophil migration, production of reactive oxygen species (Rambeaud and Pighetti, 2005), and release of intracellular calcium (Rambeaud and Pighetti, 2007). The c.337A $>$ G SNP changed the 113th amino acid from isoleucine to valine, whereas the c. $365 \mathrm{C}>\mathrm{T}$ mutation changed alanine to valine at position 122 within the putative $3 \mathrm{rd}$ intercellular loop of the receptor region for $\mathrm{G}$ protein coupling activation of CXCR1 (360 amino acids). Thus, these amino acid changes in CXCR1 potentially influence neutrophil function and disease resistance, because the product of the CXCR1 gene is a receptor for interleukin-8, a key regulator of neutrophil migration, killing, and survival (Glynn et al., 2002).

Moreover, the effect of the c.337A $>\mathrm{G}$ and c.365C $>$ T SNPs on the 3-dimensional protein structure was also predicted using SWISS-MODEL, to demonstrate how the two SNPs modify. However, no significant differences in the whole structure of CXCR1 pre- and postmutations were observed (Figure 4). This result was somewhat unexpected because of the variation observed in the structure of the receptors (Rambeaud et al., 2006; Stillie et al., 2009), which may affect neutrophil function and disease resistance. A variety of factors contributed to the lack of differences in the 3-dimensional structure. No significant differences in CXCR1 structure pre- and post-mutation may allow complete receptor expression of the intracellular loop and the transmembrane domain to fulfill the chemotaxis mediation (Lahouassa et al., 2008). Further studies are being conducted to evaluate these possibilities.

Compared with SNPs, haplotypes are likely to exert a greater effect on traits (Capparelli et al., 2008). In addition, haplotype analysis is more comprehensive than single-locus analysis (Fallin et al., 2001). The present study found haplotype combinations in Holstein cattle. Subjects with the H2H6 haplotype combination had the highest 305-day milk yield. The cows with $\mathrm{H} 1 \mathrm{H} 7$ had higher fat percentage, whereas those with $\mathrm{H} 5 \mathrm{H} 6$ had higher protein percentage. The cows with $\mathrm{H} 1 \mathrm{H} 3, \mathrm{H} 1 \mathrm{H} 6$, and H2H6 exhibited lower SCS values. Therefore, the 
$\mathrm{H} 2 \mathrm{H} 6, \mathrm{H} 1 \mathrm{H} 7, \mathrm{H} 5 \mathrm{H} 6, \mathrm{H} 1 \mathrm{H} 3, \mathrm{H} 1 \mathrm{H} 6$, and $\mathrm{H} 2 \mathrm{H} 6$ haplotype combinations are potential markers for higher milk production, higher fat rate, higher protein rate, and better mastitis resistance.

Differences in allelic and genotypic frequencies of the 4 SNPs in bovine CXCRI among Chinese Holstein cattle, Luxi Yellow cattle, and Bohai Black cattle may be caused by long-term artificial selection, based on the Hardy-Weinberg equilibrium. The Chinese Holstein breed was cultured as dairy cattle through cross-breeding between the native cows and imported purebred Holstein bulls via artificial insemination to improve the milk production traits of native breeds. Luxi Yellow cattle and Bohai Black cattle have been bred as beef and draft dual-purpose and as important beef sources for hundreds of years (Qiu, 2002). The high frequencies of the C, C, $\mathrm{A}$, and $\mathrm{C}$ variants of $C X C R 1$ in these three Chinese native breeds suggest that these alleles may affect the bovine immune system. One possible explanation is that CXCR1 deficiency helps protect the host against infection by regulating host neutrophil migration, killing, and survival. Another proposed reason is that the high frequency of mutations in these native breeds reduces the damaging effects of excessive inflammatory reaction activation.

Real-time PCR studies of different genotype mammary tissues from adult mastitic Chinese Holstein cows were performed to test the aforementioned hypothesis. The results indicated differential expression in different genotypes at the c.337A $>\mathrm{G}$ and c.365C $>\mathrm{T}$ loci of the bovine $C X C R 1$ gene. The $C X C R 1$ expression level of cows with the c.337 A>G-GG genotype was significantly higher than those with the c.337A $>$ G-AA genotype $(\mathrm{P}<0.05)$, which suggests that the polymorphic sites studied influence the expression of the bovine CXCRI gene. This phenomenon may be a defense mechanism that developed when the mammary glands of Chinese Holstein cattle were infected by pathogens. When mastitis occurs, CXCR1 proteins are synthesized to protect the gland by increasing neutrophil trafficking to the mammary gland. The bovine CXCR1 expression pattern in this study is similar to that reported by $\mathrm{Li}$ et al. (2011), where the expression of the HSF1TT-4693 genotype in the liver was 2.84 times higher than that of the GG-4693 genotype. However, CXCR1 expression with c.365C > T-CT was 1.5 -fold higher than with the c.365C $>\mathrm{T}$-TT genotype, but the difference was considered to be statistically insignificant. This result is possibly explained by the different CXCR1 protein variants and the possibility that $C X C R 1 \mathrm{mRNA}$ was unaffected by the c.365C $>\mathrm{T}$ SNP. The c. 365C $>$ T SNP may participate in the defense mechanism of the cow mammary glands, but not at the mRNA level. Another possible reason may be that other SNPs may affect mastitis resistance, because the bovine $C X C R 1$ gene is highly polymorphic (Pighetti et al., 2012). Therefore, the $C X C R 1$ variants in mammary glands need further investigation.

Further studies are needed to confirm the association of the SNPs with SCS. Moreover, the possible associations of c.337A $>\mathrm{G}$ and c.365C $>\mathrm{T}$ with mastitis resistance and the occurrence of preferable haplotypes within the $C X C R 1$ gene are interesting topics for future studies. The findings of this study suggest that the $C X C R 1$ gene is a possible DNA marker for bovine mastitis resistance, which may assist in marker-assisted selection.

\section{ACKNOWLEDGMENTS}

Research supported by the National Anti-TB Transgenic Project (\#2011ZX08007004), the National Science and Technology Pillar Program during the 12th Five-Year Plan (\#2011BAD19B04), the China Agriculture Research System (Grant \#CARS-37), and the Key Scientific and Technological Project of Shandong Province (\#2009GG20002033). 


\section{REFERENCES}

Arnold K, Bordoli L, Kopp J and Schwede T (2006). The SWISS-MODEL Workspace: a web-based environment for protein structure homology modelling. Bioinformatics 22: 195-201.

Capparelli R, Parlato M, Amoroso MG, Roperto S, et al. (2008). Mannose-binding lectin haplotypes influence Brucella abortus infection in the water buffalo (Bubalus bubalis). Immunogenetics 60: 157-165.

Del Rio L, Bennouna S, Salinas J and Denkers EY (2001). CXCR2 deficiency confers impaired neutrophil recruitment and increased susceptibility during Toxoplasma gondii infection. J. Immunol. 167: 6503-6509.

Dewald O, Zymek P, Winkelmann K, Koerting A, et al. (2005). CCL2/monocyte chemoattractant protein-1 regulates inflammatory responses critical to healing myocardial infarcts. Circ. Res. 96: 881-889.

Fallin D, Cohen A, Essioux L, Chumakov I, et al. (2001). Genetic analysis of case/control data using estimated haplotype frequencies: application to APOE locus variation and Alzheimer's disease. Genome Res. 11: 143-151.

Glynn PC, Henney E and Hall IP (2002). The selective CXCR2 antagonist SB272844 blocks interleukin-8 and growth-related oncogene-alpha-mediated inhibition of spontaneous neutrophil apoptosis. Pulm. Pharmacol. Ther. 15: 103-110.

Goertz I, Baes C, Weimann C, Reinsch N, et al. (2009). Association between single nucleotide polymorphisms in the CXCR1 gene and somatic cell score in Holstein dairy cattle. J. Dairy Sci. 92: 4018-4022.

Gonzalez-Escribano MF, Torres B, Aguilar F, Rodriguez R, et al. (2003). MCP-1 promoter polymorphism in Spanish patients with rheumatoid arthritis. Hum. Immunol. 64: 741-744.

Grosse WM, Kappes SM, Laegreid WW, Keele JW, et al. (1999). Single nucleotide polymorphism (SNP) discovery and linkage mapping of bovine cytokine genes. Mamm. Genome 10: 1062-1069.

Günther J, Koczan D, Yang W, Nurnberg G, et al. (2009). Assessment of the immune capacity of mammary epithelial cells: comparison with mammary tissue after challenge with Escherichia coli. Vet. Res. 40: 31.

Kehrli ME Jr and Harp JA (2001). Immunity in the mammary gland. Vet. Clin. North Am. Food Anim. Pract. 17: 495-516.

Lahouassa H, Rainard P, Caraty A and Riollet C (2008). Identification and characterization of a new interleukin-8 receptor in bovine species. Mol. Immunol. 45: 1153-1164.

Lee JW, Bannerman DD, Paape MJ, Huang MK, et al. (2006). Characterization of cytokine expression in milk somatic cells during intramammary infections with Escherichia coli or Staphylococcus aureus by real-time PCR. Vet. Res. 37: 219-229.

Leyva-Baca I, Schenkel F, Martin J and Karrow NA (2008). Polymorphisms in the 5' upstream region of the CXCR1 chemokine receptor gene, and their association with somatic cell score in Holstein cattle in Canada. J. Dairy Sci. 91: 407-417.

Li QL, Ju ZH, Huang JM, Li JB, et al. (2011). Two novel SNPs in HSF1 gene are associated with thermal tolerance traits in Chinese Holstein cattle. DNA Cell Biol. 30: 247-254.

McDermott DH, Yang Q, Kathiresan S, Cupples LA, et al. (2005). CCL2 polymorphisms are associated with serum monocyte chemoattractant protein-1 levels and myocardial infarction in the Framingham Heart Study. Circulation 112: 1113-1120.

Oviedo-Boyso J, Valdez-Alarcon JJ, Cajero-Juarez M, Ochoa-Zarzosa A, et al. (2007). Innate immune response of bovine mammary gland to pathogenic bacteria responsible for mastitis. J. Infect. 54: 399-409.

Paape MJ, Shafer-Weaver K, Capuco AV, Van Oostveldt K, et al. (2000). Immune surveillance of mammary tissue by phagocytic cells. Adv. Exp. Med. Biol. 480: 259-277.

Papachristou GI, Sass DA, Avula H, Lamb J, et al. (2005). Is the monocyte chemotactic protein-1 -2518 G allele a risk factor for severe acute pancreatitis? Clin. Gastroenterol. Hepatol. 3: 475-481.

Pighetti GM and Rambeaud M (2006). Genome conservation between the bovine and human interleukin- 8 receptor complex: improper annotation of bovine interleukin-8 receptor b identified. Vet. Immunol. Immunopathol. 114: 335-340.

Pighetti GM, Kojima CJ, Wojakiewicz L and Rambeaud M (2012). The bovine CXCR1 gene is highly polymorphic. Vet. Immunol. Immunopathol. 145: 464-470.

Proudfoot AE (2002). Chemokine receptors: Multifaceted therapeutic targets. Nat. Rev. Immunol. 2: 106-115.

Qiu H (2002). Modern dairy science. Agr. Press China 1: 12.

Rainard P and Riollet C (2006). Innate immunity of the bovine mammary gland. Vet. Res. 37: 369-400.

Rambeaud M and Pighetti GM (2005). Impaired neutrophil migration associated with specific bovine CXCR2 genotypes. Infect. Immun. 73: 4955-4959.

Rambeaud M and Pighetti GM (2007). Differential calcium signaling in dairy cows with specific CXCR1 genotypes potentially related to interleukin-8 receptor functionality. Immunogenetics 59: 53-58.

Rambeaud M, Clift R and Pighetti GM (2006). Association of a bovine CXCR2 gene polymorphism with neutrophil survival and killing ability. Vet. Immunol. Immunopathol. 111: 231-238. 
Reeves EP, Lu H, Jacobs HL, Messina CG, et al. (2002). Killing activity of neutrophils is mediated through activation of proteases by K ${ }^{+}$flux. Nature 416: 291-297.

Rupp R and Boichard D (1999). Genetic parameters for clinical mastitis, somatic cell score, production, udder type traits, and milking ease in first lactation Holsteins. J. Dairy Sci. 82: 2198-2204.

Shi YY and He L (2005). SHEsis, a powerful software platform for analyses of linkage disequilibrium, haplotype construction, and genetic association at polymorphism loci. Cell Res. 15: 97-98.

Shook GE and Schutz MM (1994). Selection on somatic cell score to improve resistance to mastitis in the United States. J. Dairy Sci. 77: 648-658.

Stillie R, Farooq SM, Gordon JR and Stadnyk AW (2009). The functional significance behind expressing two IL-8 receptor types on PMN. J. Leukoc. Biol. 86: 529-543.

Tao Q, Yu MX, Zhao YH and Wang DX (2007). Survey of incidence of cow mastitis in west Liaoning and the integrated control measures. China Cattle Sci. 4: 61-63.

Wang C, Liu M, Li Q, Ju Z, et al. (2011). Three novel single-nucleotide polymorphisms of MBL1 gene in Chinese native cattle and their associations with milk performance traits. Vet. Immunol. Immunopathol. 139: 229-236.

Youngerman SM, Saxton AM, Oliver SP and Pighetti GM (2004a). Association of CXCR2 polymorphisms with subclinical and clinical mastitis in dairy cattle. J. Dairy Sci. 87: 2442-2448.

Youngerman SM, Saxton AM and Pighetti GM (2004b). Novel single nucleotide polymorphisms and haplotypes within the bovine CXCR2 gene. Immunogenetics 56: 355-359.

Zdobnov EM and Apweiler R (2001). InterProScan - an integration platform for the signature-recognition methods in InterPro. Bioinformatics 17: 847-848. 